\title{
EXCELLENCE IN ACCOUNTANCY
}


Also by Bob Reynolds

THE 100 BEST COMPANIES TO WORK FOR IN THE UK 


\section{Excellence in Accountancy}

Bob Reynolds 
(C) Bob Reynolds 1993

Softcover reprint of the hardcover 1st edition 1993

All rights reserved. No reproduction, copy or transmission of this publication may be made without written permission.

No paragraph of this publication may be reproduced, copied or transmitted save with written permission or in accordance with the provisions of the Copyright, Designs and Patents Act 1988, or under the terms of any licence permitting limited copying issued by the Copyright Licensing Agency, 90 Tottenham Court Road, London W1P 9HE.

Any person who does any unauthorised act in relation to this publication may be liable to criminal prosecution and civil claims for damages.

First published 1993 by

THE MACMILLAN PRESS LTD

Houndmills, Basingstoke, Hampshire RG21 2XS

and London

Companies and representatives

throughout the world

ISBN 978-1-349-12087-1 ISBN 978-1-349-12085-7 (eBook)

DOI 10.1007/978-1-349-12085-7

A catalogue record for this book is available from the British Library. 
To Kay, who makes all things possible, to Ben, bright shining light, and to Verity, the new communicator 


\section{Contents}

List of Tables viii

Acknowledgements $\quad$ ix

Introduction $\quad \mathrm{xi}$

1 The Structure of the Profession 1

2 The Market and its Demands $\quad 7$

3 The Guys with the Widest Smiles - an Overview of $\begin{array}{ll}\text { Human Resources } & 13\end{array}$

4 The Other Man's Watch - Management Consultancy 19

5 The Veuve Clicquot Set - Corporate Finance 27

6 The Voodoo Kings - Insolvency 33

7 Grow your Own - Growth Companies 41

8 It's One for You and Nineteen for Me - Tax 47

9 The Old Reliable - Audit 53

10 What Makes you Tick - Cultural Issues 61

11 The Medium is the Message - Structures Within 67

$\begin{array}{lll}12 & \text { The Future } & 73\end{array}$

$\begin{array}{ll}\text { Index } & 79\end{array}$ 


\section{List of Tables}

1 Fee Income, 1990-1 xvi

2 The World's Largest Accountancy Firms, 1990-1 xviii

3 Membership Statistics of Key Accountancy Bodies 2

4 Management Consultancy, 1991-2 (£m) 22

5 Accountant Advisers to UK Mergers and Acquisitions, $1990 \quad 30$

6 Insolvency: Fee Income, 1991-2 (£m) 35

7 Fee Income from Tax Assignments, 1991-2 (£m) 49

8 Audit Fee Incomes, 1991-2 (£m) 55

9 Fee Income of European Accountancy Firms, 1991

10 European Rankings by Staff, 1991 


\section{Acknowledgements}

Many people have given their time and expertise freely for the benefit of this project. I would like to extend my thanks to all of them in general and to those listed below specifically.

First to Kay Reynolds, who was originally joint author of this book. She completed many of the interviews which influenced the final manuscript and arranged all the meetings which shaped the text. Only the happy circumstance of the birth of Ben prevented her from completing the work.

Thanks to David Waller and Andrew Jack of the Financial Times, Peter Byrne and Anneliese Healy of Lafferty Publications for their help with the tables, John de Forte of de Forte Associates, Esther Kaposi of Wolff Olins, Michael Megarry of Countrywide, and Frances Arnold and Belinda Holdsworth of Macmillan for their kindness, guidance and professional expertise.

Thanks are due to the following individuals and their respective organisations:

Coopers \& Lybrand: Brandon Gough, Peter Allen, John Bullock, Alan McFetrich, Malcolm Coster, David Stewart, Sir Brian Jenkins, John Andrews, Neil Taberner, Andrew Warren, Chris Hughes, Richard Stone, Roderick Boswell, John Berriman, Chris Stronge, Tony Bartlett, Ed Straw, Ron Collard, Ian du Pré, Geoff Smart, Oriana Pound, Peter Ward and JulieAnne Wildman.

KPMG Peat Marwick: Jim Butler, Colin Sharman, David Clifford, Michael Fowle, Gerry Archer, Robin Linnecar, Alistair Johnston and Roger White.

Ernst \& Young: Elwyn Eilledge, Michael Knight, Nigel Moore, Nigel Hamilton, Francis Small, John Howell and Andrew Oakley.

Price Waterhouse: Ian Brindle, Howard Hughes, Roger Seekings, Barry Baldwin, John Salmon, Neville Cheadle, Mark Homan, Tom Wilson, Chris Smith, Sue Hurley and Valerie Moores. 
Arthur Andersen/Andersen Consulting: Roy Chapman, Adrian Lajtha, Philip Toomey, Aram Sishamanian and Carlos Vidal.

Touche Ross: John Roques and Peter Stilling.

Grant Thornton: Mike Lickiss, David McDonnell, Philip Hardman, Darryl Whitehead, Allan Griffiths, Gary Downey, Chris Carter, Richard Brandt, Ann Baldwin, Jason Cross, Sue Palmer and Clive Bennett.

Pannell Kerr Forster: Claude Brown, Tim Richmond, Michael Bridge, Guy Bigland, Alan Cull, Steve Bruck, Mike Fitzsimmonds and Alan Hopper.

Stoy Hayward: Philip Sober, Paul Hipps, Adrian Martin, Peter Copp, Mike Haan, Roger Roberts, Peter Leach, Alan Cinnamon, Stephen Greene, Dermot Mathias and Michael Grunberg.

Moores Rowland: Cyril Dashwood, Victor Clements, Robin Stevens, Brian Gillega, John Blanquiere and Leslie Livens.

Clark Whitehill: Jim Gemmel, Hugh Butterworth, Roger Downes, Robin Gorringe, Lesley Goodlett, David Furst and David Davis.

Neville Russell: Alan Dyer, Marc Vouters, George Bull, John White, John Mellows and James Mendlessohn.

Robson Rhodes: Hugh Aldous, Frank Attwood, Nicholas Andrew, Graham Sidwell and Neil Cooper.

Baker Tilly: Clive Parritt, Richard Blake, Peter Bessler, Lynne Marcus, Richard White, Tony Pierre and Walter Hoffman. 


\section{Introduction}

Britain's accountancy profession has never been through a more turbulent time. It met the challenge of expansion and diversification in the late 1970s and early 1980s head on. Its reputation and influence grew. The traditional concept of accountant as professional but supine was substituted. A new image of adviser and intimate to the captains of industry has emerged. At least the men who steer the largest practices would have us believe that the former role has been exchanged for the latter.

However, the experiences of the 1990s have not been altogether easy. The mega-mergers, for all their vaunted client service benefits, have drawn heavily on resources, and the corporate financial collapses of the latest recession have served to dent credibility in the performance of the auditor and his relationship with his client. The latest authoritative client attitude survey shows a general debasement in perceptions of client service by accountancy firms. Accountants are not alone in this. They are part of an ongoing, general trend of public reassessment of national institutions.

The marketing departments of the Big Six have had to fight hard during these last couple of years to keep the picture of the professional unmuddied. Somehow the idea that the accountant was primarily in business for the public good and to assist in the orderly and effective management of companies has gone out of the window. Unconvincing arguments against separating statutory and consultancy functions may need bolstering in the time ahead. Firms may come under pressure for direct supervision by a strict City regulatory agency. Accountants have also experienced pressure on price. One of the larger firms says that it is now charging a third to a half of fees of two years ago. It is not the only firm facing this problem. It is hard to see how charges can regain their former level when the recession gives way to a more prosperous period. Some audit fees are now charged out at a half to two-thirds of 1989 levels. As income growth falters, costs are increasing and some of the more ambitious property commitments of the 1980s are now viewed as mistaken.

The firms as they are constituted today are the products of two trends of the 1980s. The first might be termed the Thatcher approach, since she presided over it, if not actually directed it. Companies became more commercial and demanded more from their suppliers. As they became increasingly global so their suppliers needed to follow suit. The second trend, 
although reflecting the greater commercialisation of the age, was largely an internal factor. Audit and the other compliance services were seen as a static market. The accountants perceived opportunities in the consultancy field and their huge growth statistics of the latter part of the decade were due largely to selling consultancy services.

The Big Six's marketing departments, originally fairly sickly infants, managed to create the myth of the modern accountant. The larger firms eagerly sought a piece of the action in the rapidly expanding City. The new model accountant emerged out of the shadows to become a forwardlooking, hard-driving and multi-talented individual. The change could not have been more striking. Partners soon became apparent experts in a plethora of business topics such as marketing, distribution, retail management, recruitment, information technology, human resource planning and communications.

The transformation brought the firms into contact with an enlarged schedule of competitors. However, the bulk of competition lay within their own ranks - other firms of chartered and certified practitioners. Now, the larger practices pitted themselves against the existing management consultants such as PA, Imbucon, PE and McKinsey. In the mid-1980s the Big Six moved on to tackle the second-tier merchant banks by wresting significant corporate finance work away. By 1990 all of the top twenty accountants were reporting major investment in corporate finance facilities.

As the marketplace widened, the fight for the heartland - audit and accounting - became bitter. In 1986 the value of the audit market in the UK was placed at $£ 1$ billion. This amount varied very little, so the increasingly gloves-off environment meant that competition became tougher. The façade of gentlemanly behaviour dissolved as firms scrambled to retain their position and carve out a larger portion for themselves. The stability of the audit relationship could no longer be relied upon. In the past, companies rarely changed their auditors. Now, young thrusting executives keen to make their fortune before their thirtieth birthday took over the helm in some of the largest enterprises.

Corporate leaders wanted accountants who understood their increasingly demanding financial objectives and who sympathised with the aims of controlling overheads and maximising profit. The round of corporate takeovers also meant that tenure for life was no longer a realistic proposition. The new operators of companies changed auditors with mind-boggling rapidity. The beauty parade emerged as a regular feature of the drive to retain existing clients and add new ones. The quality and innovation of proposals for audit work assumed an increasing importance. Consumer and 
competitor intelligence units found favour in the audit battle. New products were pushed into the market by the bigger and bigger firms attempting to meet and to anticipate demand. Client service emerged as the key issue which dominated thinking, and client service partners became the darlings and prima donnas of the profession.

As a result of this catalogue of changes, accountants came under greater scrutiny. The accountant is engaged by the shareholders of a business yet the vast majority of dealings are with management. This can mean that the accountant is drawn in at least two directions, since the interests of management and shareholders are not always identical. Where does the accountant's loyalty belong in cases of potential conflict? It is not always straightforward. At worst, a blind eye may be turned to fraudulent practice. Certain Opposition politicians are concerned that the independence of the audit opinion, which is the essential raison d'être for the accountant's involvement, could be jeopardised. The audit is a statutory obligation. The fee for the accountant is welcome but the cream and jam on the slice is consultancy. Advising the client on a whole range of commercial matters such as international tax, foreign exchange, IT installation and pricing policy is vastly more lucrative than supplying the audit. Is there a tendency among auditors to provide a clean bill of health in order to generate consultancy work?

Attention has been focused on the quality of audit work, especially by the majors, after the failure of companies such as Maxwell, BCCI, Olympia \& York, Polly Peck, British \& Commonwealth and Sock Shop. Shareholders have asked how companies have collapsed only months after favourable audit reports. The dilemma brings into question the value of the audit and nature of the relationship between the auditor and his client. When questioned about the potential conflict for auditors in supplying consultancy services to clients, practitioners take the veil of professionalism. It would be unthinkable, they say, to compromise their independence. Besides it would be commercially insane. This is regarded as pretty thin by the profession's detractors.

The role of the auditor has always been to see that the accounts kept by a limited company are 'true and fair'. This phrase says nothing about detection of fraud and therefore the onerous public duty of reporting fraud does not fall, as an obligation, to accountants. The issues of the quality and reliability of the audit, the separation of statutory and consultancy functions, and the detection of fraud are all interconnected. They represent pressures on the modern profession which could result in an extension of regulation. 
As part of the legislative machinery which accompanied the Financial Services Act, chartered accountants sought self-regulatory status. The impact of diverse influences such as European Directives, the collapse of major companies favourably audited and political pressure could lead to more extensive regulation for the profession. An even greater impetus could, paradoxically, emerge from an unwillingness by the profession to establish a single representative institution. At present six bodies - three chartered plus the certified association, the management accountants' institute and CIPFA for local government - comprise the official representatives of the profession. Government clearly regards this as little short of farcical.

During the last half of the 1980s, there has been a rapid escalation in the pace of merger, takeover and assimilation of accountancy practices. The much vaunted one-stop shops of accountants, lawyers, actuaries and other professionals failed to materialise, but there has been widespread merger and acquisitional activity among the accountancy firms themselves. The latest wave was set in motion by the merger of KMG with Peat Marwick in 1985. Ernst \& Whinney, itself the product of several mergers, linked up with the failing Arthur Young; Coopers \& Lybrand swallowed up Deloitte, Haskins \& Sells; the highly regarded British arm of Spicer \& Oppenheim went to Touche Ross. Not all the proposed mergers materialised. Notably, Price Waterhouse, regarded by many as the standard bearer for the profession, has failed to merge with Deloitte and Arthur Andersen. Andersen itself separated out its consultancy into a distinct unit as Andersen Consulting.

The result of this frenetic activity was, at first, confusion among clients, staff and intermediaries. Where a particular firm has an identifiable approach to its work which is valued by its clients then merger can cause disturbance. Things have settled down since the 1990 mergers and some of the early identity problems have been resolved. The firms argue that to provide the multinational client with the excellent level of service which is required today international firms must have a critical mass. They say that they must be able to provide the same level of client care in every location around the world. In some cases the mergers go through with ease. In others national affiliates spin off, preferring to associate with other international firms. The structure of these organisations is important. Each individual national firm is a partnership which agrees to do business with a firm, usually of the same name, in another territory. These are not unitary or even homogeneous cultures. They are separate businesses which agree to trade under the same logo. They agree to share a common approach to servicing 
clients and to the way in which they achieve their goals. Determining how successful these businesses are is a fraught task.

Unlike the bulk of their clients, they do not publish profit figures. Fee income is recorded annually in a range of journals, notably the Financial Times and Accountancy Age. This equates with turnover. Growth over previous years is a helpful indicator but the real indicators are fees per partner and fees per partner and professional staff. Until accountants are obliged to publish profit figures, these ratios offer some light in a gloomy world.

The core of the business relationship between an accountant and the client is a personal one. Whatever the size of the institution providing the service, in the end personality plays a dominant role. Whether the accountant is a senior client handler in Coopers, Price Waterhouse or Andersen or a solo practitioner in the high street, the excellence of the work and of that relationship is the determining factor in the selection and retention of a particular supplier. In setting out to find excellence in accountancy we have been acutely aware of the excellent work done by a wide range of individuals around the country. What we have tried to do is identify what makes for good practice in the sectors we have come to see as the principal areas in which accountants operate - the product areas. We have also looked at organisational and structural questions, and finally at the vexed issue of personnel. We are lucky that we have extensive experience of the profession and that accountants gave so freely of their time to contribute to this project. We have also been influenced by two previous books: Excellence in Banking and Managing Change in the Excellent Banks.

We have not set out to devise a structure which states that certain practice is excellent while a contrary approach does not work. We have listened to many practitioners across the broad span of modern accountancy. We have also listened to their clients, accountancy academics, critics of the accountants and the press, which is not always impartial. We learned very quickly that there is one firm which has been universally respected and feared - by its competitors for the quality of its service. Above all, its people have been seen as standard bearers for the profession. Their intelligence is matched by their culture. The partners and staff of Price Waterhouse, in common with their colleagues throughout the profession, show determination to achieve their client goals, but Price Waterhouse is distinctive in that it appears to have created a culture which spawns an approach to client service and problem solving which is the envy of the sector. The PW people have had a happy knack of commanding personal authority while losing 


\begin{tabular}{|c|c|c|c|c|c|}
\hline Rank & Firm & $\begin{array}{c}\text { Total } \\
1990 / 91 \\
(£ m)^{*}\end{array}$ & $\begin{array}{c}\text { Change } \\
90 / 91 \\
\%\end{array}$ & $\begin{array}{c}\text { Audit } \\
(£ m)\end{array}$ & $\begin{array}{c}\text { Mgmt. } \\
\text { Consultancy } \\
(£ m)\end{array}$ \\
\hline 1 & Coopers \& Lybrand Deloitte ${ }^{\dagger}$ & 588.0 & 11.1 & 260.0 & 142.0 \\
\hline 2 & KPMG Peat Marwick McLintock & 467.1 & 18.2 & 257.9 & 80.4 \\
\hline 3 & Price Waterhouse ${ }^{\dagger \dagger / \Phi}$ & 377.4 & 25.8 & 151.3 & 103.0 \\
\hline 4 & Ernst \& Young ${ }^{\Phi}$ & 358.3 & 6.2 & 168.3 & 57.9 \\
\hline 5 & Touche Ross ${ }^{\Phi \Phi /+\dagger \dagger / \star}$ & 294.9 & 17.9 & 145.9 & 51.0 \\
\hline 6 & Arthur Andersen ${ }^{\Phi / \S}$ & 268.8 & 32.2 & 67.0 & 134.3 \\
\hline 7 & BDO Binder Hamlyn ${ }^{\Phi \Phi \Phi}$ & 119.7 & 13.5 & 63.4 & 6.0 \\
\hline 8 & Grant Thornton $^{\Phi}$ & 115.3 & 12.5 & 45.7 & 4.5 \\
\hline 9 & Pannell Kerr Forster ${ }^{\Phi \Phi \Phi}$ & 84.6 & 11.0 & 46.1 & 3.8 \\
\hline 10 & Stoy Hayward ${ }^{\Phi}$ & 66.6 & 13.3 & 34.4 & 10.2 \\
\hline 11 & Moores Rowland ${ }^{\Phi \Phi \Phi / \S \S}$ & 65.3 & 14.6 & NA & NA \\
\hline 12 & Kidsons Impey ${ }^{\Phi \Phi \Phi}$ & 57.5 & 7.1 & 33.4 & 4.0 \\
\hline 13 & Clark Whitehill $^{\Phi}$ & 56.8 & 5.8 & 38.0 & 2.3 \\
\hline 14 & Robson Rhodes ${ }^{\Phi \Phi \Phi}$ & 35.0 & 2.6 & 13.9 & 2.0 \\
\hline 15 & Neville Russell ${ }^{\Phi \Phi \Phi}$ & 34.8 & 8.1 & 20.2 & 3.6 \\
\hline 16 & Moore Stephens ${ }^{\S \S}$ & 34.6 & 18.7 & 15.4 & 8.4 \\
\hline 17 & Baker Tilly $^{\Phi \Phi \Phi}$ & 25.6 & 11.8 & 11.5 & 2.4 \\
\hline 18 & Haines Watts ${ }^{\Phi \Phi \Phi}$ & 20.2 & 20.1 & NA & NA \\
\hline 19 & Macintyre Hudson ${ }^{\Phi \Phi \Phi}$ & 16.7 & 14.4 & NA & NA \\
\hline 20 & Saffery Champness ${ }^{\Phi \Phi \Phi}$ & 16.3 & 11.6 & NA & NA \\
\hline
\end{tabular}

NoTES: "net of recoverable expenses; 'Including Northern Ireland but excluding Channel Islands \& Isle of Man; ${ }^{\dagger \dagger}$ including Channel Islands, Isle of Man \& Northern Ireland, ${ }^{\dagger \dagger} \mathrm{UK}$ only excluding Channel Islands \& Isle of Man; ${ }^{\Phi} \mathrm{y} / \mathrm{e} 31.3 ;{ }^{\Phi \Phi} \mathrm{y} / \mathrm{e} 15.4$; ${ }^{\Phi \Phi \Phi}$ y/e 30.4.; ${ }^{\S}$ firm changed its Management Consultancy figures for $1989 / 90$ from $£ 86.1 \mathrm{~m}$ to $£ 95 \mathrm{~m}$ (on a turnover basis, consistent with the rest of consulting industry); ${ }^{\S}$ includes UK MRI associates.

Moores Rowland's fee income was $£ 32.5 \mathrm{~m}$; $\$ \$$ y/e 31.12.; Coopers \& Lybrand Deloitte y/e 28.4.; ${ }^{\star}$ the current \& prior year figures include results of Spicer \& Oppenheim who merged with Touche Ross in the UK on 20.6.1990. Figures for the parts of Spicer \& Oppenheim which did not merge with Touche Ross are excluded. Figures in the Fee Income split may not add up due to the rounding and in some instances some categories do not fall into Audit/Consultancy/tax/insolvency categories.

SOURCE: Financial Times, June 1991. Research by Jan Schling. 


\begin{tabular}{|c|c|c|c|c|c|c|}
\hline $\begin{array}{c}\operatorname{Tax} \\
(£ m)\end{array}$ & $\begin{array}{c}\text { Insolvency } \\
(£ m)\end{array}$ & Partners & $\begin{array}{l}\text { Prof. } \\
\text { staff }\end{array}$ & $\begin{array}{c}\text { Prof. } \\
\text { staff/ } \\
\text { partner } \\
\text { ratio }\end{array}$ & $\begin{array}{c}\text { Fees/ } \\
\text { partner } \\
\text { ratio } \\
(£ 000)\end{array}$ & $\begin{array}{c}\text { Fees/total } \\
\text { prof. staff } \\
\text { ratio } \\
\left({ }^{\prime} 000\right)\end{array}$ \\
\hline 122.0 & 64.0 & 735 & 7,807 & 10.62 & 800.00 & 68.84 \\
\hline 92.2 & 36.6 & 591 & 7,793 & 13.19 & 790.36 & 55.71 \\
\hline 95.5 & 27.6 & 482 & 5,160 & 10.70 & 782.99 & 66.89 \\
\hline 102.9 & 29.2 & 421 & 5,552 & 13.19 & 851.07 & 59.99 \\
\hline 68.4 & 29.6 & 407 & 4,425 & 10.87 & 724.57 & 61.03 \\
\hline 55.2 & 12.3 & 209 & 2,931 & 14.02 & $1,286.12$ & 85.61 \\
\hline 37.1 & 6.0 & 231 & 2,042 & 8.84 & 518.18 & 52.66 \\
\hline 30.6 & 21.2 & 247 & 1,952 & 7.90 & 466.80 & 52.43 \\
\hline 22.0 & 9.1 & 220 & 1,835 & 8.34 & 384.55 & 41.17 \\
\hline 13.0 & 9.0 & 134 & 1,191 & 8.89 & 497.01 & 50.26 \\
\hline NA & NA & 254 & 1,538 & 6.06 & 257.09 & 36.44 \\
\hline 15.0 & 5.1 & 178 & 1,227 & 6.89 & 323.03 & 40.93 \\
\hline 13.0 & 0.6 & 227 & 1,398 & 6.16 & 250.22 & 34.95 \\
\hline 8.8 & 6.2 & 70 & 523 & 7.47 & 500.00 & 59.02 \\
\hline 9.0 & 2.0 & 87 & 609 & 7.00 & 400.00 & 50.00 \\
\hline 8.8 & 0.8 & 123 & 698 & 5.67 & 281.30 & 42.14 \\
\hline 5.6 & 1.3 & 59 & 397 & 6.73 & 433.90 & 56.14 \\
\hline NA & NA & 44 & 354 & 8.05 & 459.09 & 50.75 \\
\hline NA & NA & 53 & 338 & 6.38 & 315.09 & 42.71 \\
\hline NA & NA & 39 & 269 & 6.90 & 417.95 & 52.92 \\
\hline
\end{tabular}


Table 2 The World's Largest Accountancy Firms, 1990-1

\begin{tabular}{lll}
\hline Rank Name & Fee income (US \$m) \\
\hline
\end{tabular}

Worldwide rankings

$\begin{array}{rlr}1 & \text { KPMG } & 5,400 \\ 2 & \text { Ernst \& Young } & 5,006 \\ 3 & \text { DRT } & 4,200 \\ 3 & \text { Arthur Andersen } & 4,200 \\ 5 & \text { Coopers \& Lybrand } & 4,100 \\ 6 & \text { Price Waterhouse } & 2,881 \\ 7 & \text { BDO Binder } & 1,005 \\ 8 & \text { Grant Thornton } & 875 \\ 9 & \text { Horwath } & 720 \\ 10 & \text { Moores Rowland } & 639 \\ 11 & \text { DRMP } & 542\end{array}$

Worldwide rankings by income per partner (US\$)

\begin{tabular}{rlr}
1 & Arthur Andersen & $1,815,000$ \\
2 & Price Waterhouse & 958,000 \\
3 & Ernst \& Young & 892,000 \\
4 & KPMG & 857,000 \\
4 & DRT & 857,000 \\
6 & Coopers \& Lybrand & 854,000 \\
7 & Clark Kenneth & 753,000 \\
8 & Grant Thornton & 641,500 \\
9 & BDO & 608,000 \\
10 & Neville Russell & 606,000 \\
\hline
\end{tabular}

SOURCE: International Accounting Bulletin, various issues (1990-1).

none of their friendliness. Ian Brindle, UK senior partner, says if he knew the recipe for the cultural mix he would be making far more money than he is now: 'I respect all my competitors. Each of the other five in the Big Six has won work from us from time to time so I regard each one as a threat.'

Price Waterhouse has not been alone among the larger firms in experiencing the disorientating impact of the recession on confidence among staff and partners. Significant changes in structure and a leap in generation of top management had not worked their way through the firm at the time of writing.

The apparent completeness of the PW approach is probably its distinctive factor. All the other firms are good in specific areas but none enjoys 
such comprehensive achievement. Although PW partners may take all their competitors into account, it is the approach of Andersen and, perhaps, Peats which impinges most on their thoughts. PW cannot afford to rest on its laurels, however. The BCCI affair will reverberate around the profession for many years to come and may even result in some court appearances. The recent change of generation in management of the firm has not been completed without some pain. Also, clients may question what it is they are getting for their money and demand a radical reappraisal of the services supplied to them. The last two years have not been kind to PW. One leading competitor argues: 'I have always admired PW's capacity to inspire a sparkling reputation in the market. The firm enjoys a substantial lead in market appreciation. But to what extent that will be reshaped in the next few years is hard to tell.'

Arthur Andersen and Anderson Consulting also enjoy a dynamic culture. The reputation of the UK audit and tax firm goes well beyond its market share. It was a latecomer to the British scene, arriving in 1957. Some 50 per cent of its combined income is drawn from consultancy and its systems work is rightly renowned. Its international standing, its zeal to conform to exacting client service standards and its consistent drive for quality all contribute to its powerful performance. Andersen Consulting is universally regarded as the single most effective information technology (IT) consultancy among the Big Six. In 1991-2 the firm increased its income by 32 per cent. This was at a time when other firms experienced either decline or growth in a handful of percentage points.

By the time this book is published further mergers are likely to have happened. The serious press is alive with rumours of Big Six players scooping up Binder Hamlyn and Pannell Kerr Forster. Undoubtedly there will be more. The firms in the bracket from seven to twenty are being squeezed. Their larger clients are being sliced away by energetic and cashhappy Big Six partners. Some survive but only those which have a niche furrow to plough or those which can offer distinctive service.

We have attempted to show excellence at work in the accountancy profession today. In some cases we have identified individual firms or practitioners where we have seen them displaying excellence. This does not mean that there are not others doing as well all over the country. When we have asked for a definition of excellence it has generally been seen as a standard of quality in client service, but it is more than that. The modern firm survives through a variety of operational techniques, the quality of its structure, the efficiency of its marketing and how it treats its people. We have attempted to reflect these aspects of its personality. 